\title{
DOMESTIC ANIMALS AS POTENTIAL RESERVOIR HOSTS OF TRYPANOSOMA BRUCEI GAMBIENSE IN SLEEPING SICKNESS FOCI IN CAMEROON
}

\author{
NJIOKOU F.*, NIMPAYE H.*, SIMO G.**, NJITCHOUANG G.R.*, ASONGANYI T.***, CUNY G.***** \& HERDER S.*****
}

\section{Summary :}

An explanation of the endemic nature and/or the resurgence of Human African Trypanosomiasis (HAT) in the historic foci in West and Central Africa may be the existence of an animal reservoir. In some HAT foci, pigs were found infected by Trypanosoma brucei gambiense but the implication of the other domestic animals was not quite evaluated. This study aims to determine the prevalence of T. b. gambiense in domestic animal species (goat, sheep, pig and dogl commonly found in the four active HAT foci in Cameroon (Bipindi, Fontem, Campo and Doumé). Blood samples were collected from 307 pigs, 264 goats, 267 sheep and 37 dogs and used for parasitological $(Q B C)$, immunological (LiTat 1.3 CATT) and molecular (PCR) analyses. QBC detected trypanosomes in $3.88 \%$ domestic animals while $22.7 \%$ were sero-positive with LiTat 1.3 CATT tests. Of the 875 animals analysed, 174 (19.88\%) harboured T. brucei s.I. DNA, found in each of the four types of animal and in the four localities. The infection rate significantly differed among the animal species $(p<0.0001)$ and localities $(p<0.0001)$. The PCR also revealed T. b. gambiense group 1 DNA in 27 (3.08\%) domestic animals. The specific infection rates were as follows: sheep $(6.74 \%)$, goats $(3.08 \%)$, pigs $(0.32 \%)$ and dogs $(0 \%)$. T. b. gambiense was found in $8(3.92 \%)$ animals from Bipindi, 15 (4.83\%) from Campo, $4(2.59$ \%) from Fontem-Center and none from Doumé. The infection rates significantly differed between the localities, and correlated with the intensity of HAT transmission in the foci.

KEY WORDS : HTA, reservoir, domestic animal, Trypanosoma brucei s.l., T. b. gambiense group 1, PCR, CAT, QBC, sheep, goats, pigs, dogs, southCameroon.

MOTS CLÉS : FTHA, réservoir, animal domestique, T. brucei s.l., T. b. gambiense groupe 1, PCR, CATT, QBC, mouton, chèvre, porc, chien, sud-Cameroun.

\footnotetext{
* General Biology Laboratory, Department of Biology and Animal Physiology, Faculty of Science, BP 812, University of Yaoundé 1, Yaoundé, Cameroon.

** Medical Research Center, Institute of Medical Research and the Study of Medicinal Plants (IMPM), Yaoundé, Cameroon.

*** Faculty of Medicine and Biomedical Sciences, University of Yaoundé 1, Yaoundé, Cameroon.

***** Laboratoire de Recherche et de Coordination sur les Trypanosomoses IRD, UMR 177, CIRAD, TA 207/G Campus International de Baillarguet, 34398 Montpellier Cedex 5, France.

Correspondence: Flobert Njiokou, University of Yaoundé 1, Faculty of Science, BP 812, Yaoundé, Cameroon.
}

Tel.: (237) 77719631 - E-mail: njiokouf@yahoo.com
Résumé : Les animauX DOMESTIQUeS, RÉSERVOIR POTENTIEL DE TRYPANOSOMA BRUCEI GAMBIENSE DANS DES FOYERS DE MALADIE DU SOMMEIL AU CAMEROUN

Une des explications possibles de la pérennité et/ou de la résurgence des foyers historiques de la maladie du sommeil (THA) en Afrique Centrale et de l'Ouest serait l'existence d'un réservoir animal sauvage et/ou domestique de Trypanosoma brucei gambiense. Dans certains de ces foyers, le porc a été identifié comme porteur de trypanosomes susceptibles d'infecter l'homme, mais le rôle réservoir des autres animaux domestiques a été peu étudié. Cette étude a pour but de rechercher T. b. gambiense chez les animaux domestiques couramment rencontrés dans les quatre foyers actifs de la maladie du sommeil au Cameroun (Bipindi, Campo, Fontem et Doumé). Pour ce faire, des échantillons de sang y ont été prélevés sur 307 porcs, 264 chèvres, 267 moutons et 37 chiens, et analysés à l'aide de tests parasitologique (QBC), immunologique (CATT LiTat 1.3) et moléculaires (PCR à T. brucei s.l. et à T. b. gambiense groupe 1). Le QBC a permis de mettre en évidence des trypanosomes chez 3,88\% d'animaux échantillonnés alors que 22,17\% étaient séropositifs avec le test CATT LiTat 1.3. Un total de 174 (19,88\%) animaux sur 875 a été trouvé porteur d'ADN de trypanosomes du complexe T. brucei s.l. Ces échantillons positifs ont été observés chez toutes les espèces ainsi que dans toutes les localités étudiées. Ce taux d'infection diffère très significativement entre les espèces animales $(p<0,0001)$ et entre les localités $(p<0,0001)$. La PCR a également révélé la présence de l'ADN de T. b. gambiense groupe 1 chez 27 animaux, soit 3,08\%. II s'agit de 18 (6,74\%) moutons, huit (3,08\%) chèvres, un $10,32 \%)$ porc et aucun chien. Ces infections à T. b. gambiense sont observées chez 8 (3,92\%) animaux de Bipindi, 15 (4,83\%) de Campo, 4 (2,59\%) de Fontem-Centre et zéro (0\%) de Doumé. Ces pourcentages diffèrent très significativement entre les localités, et reflètent le niveau de transmission de la THA dans chacun de ces foyers.

\section{INTRODUCTION}

S leeping sickness is caused by a protozoa parasite that belongs to the Trypanosoma brucei complex in sub-Saharan Africa. The sub-species Trypanosoma brucei gambiense is the causative agent of chronic disease found in Central and West Africa; Trypanosoma brucei rhodesiense is the agent of the virulent form in East and Southern Africa while Trypanosoma brucei brucei infects only domestic and wild animals (Hoare, 1972). T. b. gambiense is divided into two sub- 
types, about $80 \%$ presenting a homogenous genetic composition and belonging to group 1 T. b. gambiense, while some $20 \%$, that are very heterogeneous belong to group 2 (Gibson et al., 1986). During the last century, the prevalence of infection in affected zones fluctuated, alternating between high and low transmission periods (Lapeyssonie, 1992; Bouteille et al., 2003). It is possible that a domestic animal reservoir of Human African Trypanosomiasis (HAT) plays a role in the epidemiology of sleeping sickness (Mehlitz, 1986). There have been many studies on the animal reservoir of T. b. gambiense (Gibson et al., 1978; Mehlitz et al., 1982, 1985; Komoin-Oka et al., 1984; Guedegbe et al., 1992). Problems of similarity in the morphology of T. b. gambiense and T. b. bruce $i$ have been progressively resolved. Thus, isoenzymes (Gibson et al., 1978; Scott et al., 1983; Nkinin et al., 2002) and amplification of sequences of microsatellite DNA (Herder et al., 2002; Jamonneau et al., 2004; Njiokou et al., 2006) specific to T. b. gambiense have confirmed the presence of this parasite in pigs and wild animals. A program for the study of animal reservoirs of sleeping sickness was initiated in Cameroon in 1999; PCR has allowed the identification of many different wild animals (primates, antelopes, rodents and small carnivores) infected with T. b. gambiense group 1 in active foci of sleeping sickness in Cameroon (Herder et al., 2002; Njiokou et al., 2006). In non-sleeping sickness zones, the same animal types did not have T. b. gambiense, although they were infected by other trypanosomes of the species complex T. brucei s.l. (Njiokou et al., 2006). In domestic animals, isoenzymes and PCR revealed the presence of $T . b$. gambiense in pigs in Fontem (Nkinin et al., 2002; Simo et al., 2006).

The present study examines the prevalence of $T . b . \mathrm{gam}$ biense in the four domestic animal species (pigs, goat, sheep and dogs) commonly found in the four most active sleeping sickness foci in Cameroon.

\section{MATERIALS AND METHODS}

\section{STUDY AREA}

T The study was carried out in 2003 and 2004 in four active sleeping sickness foci, all situated in the south of Cameroon, but presenting different epidemiological characteristics:

- Bipindi ( $\left.3^{\circ} 2^{\prime} \mathrm{N}, 10^{\circ} 22^{\prime} \mathrm{E}\right)$ is situated between Lolodorf and Kribi, $75 \mathrm{~km}$ from the sea. It is an historic focus of sleeping sickness, known since 1920, which had a resurgence recently with the diagnosis of 44 patients in 1999 (Grébaut et al., 2001). Domestic animals were bled in Bidjouka, Lambi, Memel, Ebimimbang and Bipindi Centre.

- Campo $\left(2^{\circ} 20^{\prime} \mathrm{N}, 9^{\circ} 52^{\prime} \mathrm{E}\right)$ is located at the frontier between Cameroon and Equatorial Guinea, and is under the influence of the River Ntem and the Atlantic Ocean. It is a hypo-endemic focus where a few patients are diagnosed each year. Domestic animals were bled in Ipono, Mabiogo, Akak and Campo Centre.

- Fontem $\left(5^{\circ} 40^{\prime} \mathrm{N}, 9^{\circ} 55^{\prime} \mathrm{E}\right)$ is in the South-West region of Cameroon. It is known as a focus since 1949, but its importance has since significantly reduced. It has a much varied topography, and is divided into three subfoci (North, Centre and South) (Simo et al., 2006). Domestic animals were bled in the Centre at Menji, Fotabong, Fossung, Nsoko and Azi where trypanosomiasis patients are detected each year (reports of PNLTHA). In the northern zone, no case of sleeping sickness was detected during a surveillance campaign conducted by a team from OCEAC (Organisation de Coordination de la lutte contre les Endémies en Afrique Centrale) in 1998, although up to $15 \%$ of pigs were found to be infected with T. b. gambiense groupe 1 (Nkinin et al., 2002).

- Doumé ( $\left.4^{\circ} 16^{\prime} \mathrm{N}, 13^{\circ} 25^{\prime} \mathrm{E}\right)$ is located in the Eastern Region of Cameroon. It is an old sleeping sickness focus, where patients are presently rare. It is a degraded forest zone with several streams and wetlands. Domestic animals were bled in Paki, Medim, Baillon and Loumbou.

\section{SAMPLE COLLECTION, IMMUNOLOGIC AND PARASIOLOGICAL ANALYSES}

In each focus, one of every three animals was randomly chosen to be included in the study. Bleeding was done through the jugular vein for goats and sheep, sub-clavicle vein for pigs and the saphena for dogs. The blood was collected into EDTA tubes. A LiTat 1.3 CATT (Magnus et al., 1978) was performed on each sample to detect anti-T. b. gambiense antibodies, as well as a QBC (Quantitative Buffy Coat) (Bailey et Smith, 1992). The rest of the blood was preserved at $4{ }^{\circ} \mathrm{C}$ and transported to the laboratory for molecular analyses.

\section{EXTRACTION AND AMPLIFICATION OF DNA}

In the laboratory, trypanosome DNA was extracted from the blood samples using the Ready Amp Genomic DNA purification system (PROMEGA) kit as described by Penchenier et al. (2000). The supernatant containing the DNA was stored at $-20^{\circ} \mathrm{C}$ or used directly for PCR.

A first amplification protocol to detect Trypanosoma brucei s.l., was proceeded on the extracts of all the samples using the primers TBR1 (5'-GAATATTAAA CAATGCGCAG-3')/TBR2 (5'-CCATTTATTAGCTTTGTT GC-3') (Moser et al., 1989). This was followed by a second amplification on $T$. brucei s.l. samples positive using the primers TRBPA1 (5'-GCGCCGACGATAC CAATGC-3')/TRBPA2 (5'-AACGGATTTCAGCGTT GCAG-3') (Herder et al., 2002), to detect T. b. gambiense group 1. Amplifications were proceeded in a final $25 \mu \mathrm{l}$ volume containing $10 \mathrm{mM}$ Tris-HCL ( $\mathrm{pH}$ 9), 
$50 \mathrm{mM} \mathrm{KCl}, 3 \mathrm{mM} \mathrm{MgCl}_{2}, 15$ picomoles of each primer, $200 \mu \mathrm{M}$ of each dNTP, 0.3 units of Taq DNA polymerase (Appligene-Oncor, USA), sterile water and $3 \mu \mathrm{l}$ of the DNA extract. The amplification protocol included an initial denaturing phase at $94^{\circ} \mathrm{C}$ for $3 \mathrm{~min} 30 \mathrm{sec}$, followed by 40 amplification cycles, each consisting of denaturing at $94^{\circ} \mathrm{C}$ for $30 \mathrm{sec}$, hybridization of primers at $55^{\circ} \mathrm{C}\left(\right.$ TBR1/2) or at $62^{\circ} \mathrm{C}($ TRBPA1/2), and an elongation phase at $72^{\circ} \mathrm{C}$ for $1 \mathrm{~min}$. A final elongation was achieved at $72^{\circ} \mathrm{C}$ for $5 \mathrm{~min}$. The amplification products were separated by electrophoresis on a $2 \%$ agarose gel containing $0.3 \mu \mathrm{g} / \mu \mathrm{l}$ ethidium bromide for $T$. brucei s.l. or $4 \%$ for T.b. gambiense group 1. Amplified DNA fragments were visualised and photographed under UV light.

\section{STATISITICAL ANALYSIS}

The proportion of animals positive for CATT, QBC, and PCR were compared between host species and study site using the Chi-square $\left(\chi^{2}\right)$ test performed with Statistix program.

\section{RESULTS}

\section{SEROLOGY}

f 875 animals, 194 (22.17\%) were LiTat 1.3 CATTpositive, with 95 (35.98\%) goats, 60 (19.54\%) pigs, 37 (13.85\%) sheep and two (5.40\%) dogs. All the animal species had trypanosomal antibodies. Therefore, the LiTat 1.3 CATT sero-prevalence differed significantly between the animal species $\left(\chi^{2}=\right.$ 29; $\mathrm{p}=0.0001)$. Animals LiTat 1.3 CATT-positive were identified in all the study sites: $44(14.19 \%)$ in Campo, 80 (39.21 \%) in Bipindi, 43 (27.92\%) in Fontem-Centre and $27(13.04 \%)$ in Doumé and proportion differed significantly between the study sites $\left(\chi^{2}=35 ; \mathrm{p}=\right.$ 0.0001), with the Bipindi and Fontem-Centre having the highest values.

\section{PARASITOLOGY}

A total of 34 (3.88 \%) domestic animals were QBC-positive. The specific identification of trypanosomes was not possible at this stage. All the four animal species were infected with trypanosomes in all the study sites. The proportion of infected animals was relatively high in dogs (8.1\%) and goats (5.6\%) however, the difference in infection rates between the animal species was not significant $\left(\chi^{2}=5.4 ; \mathrm{p}=0.14\right)$ (Table I). Animal infection rates were significantly higher $\left(\chi^{2}=24.5\right.$; $\mathrm{p}<$ $0.0001)$ in the sleeping sickness foci of Bipindi (8.82\%) and Fontem-Centre $(6.49 \%)$ than in the less active places (Table II).

\section{MOLECULAR ANALYSES}

PCR revealed the presence of T. brucei s.l. DNA in 174 (19.88\%) animals studied, including 82 (30.71\%) sheep, 52 (19.69\%) goats, 27 (8.79\%) pigs and 13

\begin{tabular}{lccccc}
\hline $\begin{array}{l}\text { Animals } \\
\text { sampled }\end{array}$ & $\begin{array}{c}\text { Number } \\
\text { examined }\end{array}$ & $\begin{array}{c}\text { Number } \\
\text { QBC-positive (\%) }\end{array}$ & $\begin{array}{c}\text { Number } \\
\text { CATT-positive (\%) }\end{array}$ & \multicolumn{2}{c}{ Number PCR-positive (\%) } \\
\hline Sheep & 267 & $7(2.62)$ & $37(13.85)$ & $82(30.71)$ & $18(6.74)$ \\
Goats & 264 & $15(5.6)$ & $95(35.98)$ & $52(19.69)$ & $8(3.03)$ \\
Pigs & 307 & $9(2.9)$ & $60(19.54)$ & $27(8.79)$ & $1(0.32)$ \\
Dogs & 37 & $3(8.10)$ & $2(5.40)$ & $13(35.13)$ & $0(0)$ \\
$\chi^{2}$ & & 5.40 & 29 & 32.7 & 19.5 \\
p value & 0.14 & 0.0001 & 0.0001 & 0.0002 \\
\hline
\end{tabular}

QBC: Quantitative Buffy Coat; CATT: Card agglutination Test for Trypanosomiasis; PCR: polymerase Chain Reaction; TBR: Trypanosoma brucei s.1.; TBG1: Trypanosoma brucei gambiense group 1.

Table I. - Results of different tests for the four sampled species.

\begin{tabular}{lccccc}
\hline Study site & $\begin{array}{c}\text { Number } \\
\text { examined }\end{array}$ & $\begin{array}{c}\text { Number } \\
\text { QBC-positive (\%) }\end{array}$ & $\begin{array}{c}\text { Number } \\
\text { CATT-positive (\%) }\end{array}$ & \multicolumn{2}{c}{ Number PCR-positive (\%) } \\
\cline { 5 - 6 } TBR & $80(39.21)$ & $47(23.03)$ & $8(3.92)$ \\
Bipindi & 204 & $18(8.82)$ & $44(14.19)$ & $97(31.29)$ & $15(4.83)$ \\
Campo & 310 & $5(1.61)$ & $43(27.92)$ & $24(15.58)$ & $4(2.59)$ \\
Fontem & 154 & $10(6.49)$ & $27(13.04)$ & $6(2.89)$ & $0(0)$ \\
Doumé & 207 & $1(0.48)$ & 35.7 & 46.7 & 9.9 \\
$\chi^{2}$ & & 24.5 & 0.0001 & 0.001 & 0.019 \\
p value & & 0.001 & & & \\
\hline
\end{tabular}

QBC: Quantitative Buffy Coat; CATT: Card agglutination Test for Trypanosomiasis; PCR: polymerase Chain Reaction; TBR: Trypanosoma brucei s.l.; TBG1: Trypanosoma brucei gambiense group 1.

Table II. - Number and proportion of animals positive for different tests, by study site. 
$(35.13 \%)$ dogs. There was a significant difference in PCR results between the animal species $\left(\chi^{2}=32.70\right.$; $\mathrm{p}=0.0001)$, with sheep and dogs having higher rates than goats and pigs. The number of animal positive for the PCR were 97 (31.29 \%) in Campo, 47 (23.03\%) in Bipindi, 24 (15.58 \%) in Fontem-Centre and six (2.89\%) in Doumé; with the differences statistically significant $\left(\chi^{2}=46.7 ; \mathrm{p}=0.0001\right)$.

Out of the 174 domestic animals positive for T. brucei s.l. DNA, 27 (15.5\%) had also DNA specific for T. $b$. gambiense group 1. With respect to the total number of animals studied, this represents a prevalence of $3.08 \%$ T. b. gambiense group 1, including 18 (6.74\%) in sheep, $8(3.03 \%)$ in goats, one (0.32\%) in a pig and none in dogs. These differences between species were statistically significant $\left(\chi^{2}=17.6 ; p<0.0001\right)$. By study site, 15 (4.83 \%) animals in Campo, eight (3.92 \%) in Bipindi, four (2.59\%) in Fontem-Centre and none in Doumé had T. b. gambiense group 1 DNA. The differences were significantly different between the study sites $(p=0.019)$. However, if we take into consideration only study sites were $T$. $b$. gambiense DNA were found, the prevalence becomes comparable $(\mathrm{p}=0.53)$. The 147 (84.5 \%) positive samples for T. brucei s.l. DNA but negative for $T$. $b$. gambiense group 1 DNA probably contained T. b. gambiense group 2 or T. b. brucei.

\section{DISCUSSION}

The trypanosome infection rates in the domestic animals detected with QBC (3.8\%) corroborates previous finding by other authors in domestic animals (Scott et al., 1983; Noireau et al., 1986; Asonganyi et al., 1986, 1990), and in wild animals (KomoinOka et al., 1984; Njiokou et al., 2006).

The proportion of animals LiTat 1.3 CATT-positive were generally higher than for QBC, suggesting that a high proportion of the animals had been in contact with T. b. gambiense or other parasites of the T. brucei s.l complex, or even T. congolense which also give positive results with LiTat 1.3 CATT (Noireau et al., 1986). The results confirm the constant contact between infected Glossina and these animals. Low CATT-positive prevalence in dogs with respect to QBC (8.10\%), may suggest that most of the trypanosomes in dogs do not possess the LiTat 1.3 cross-reacting antigen. This hypothesis is strengthened by the identification of T. vivax DNA in some of these dogs (data not shown). Furthermore, these results could be biased due to the low number of dogs sampled compared to other species. PCR detected parasites of the T. brucei s.l. complex in $19.88 \%$ of the animals, thus confirming the high sensitivity of the method. The results corroborates those of Simo et al. (2006) in pigs and Njiokou et al. (2006) in wild animals and are an indication of the high pre- valence of trypanosomes of the T. brucei s.l. complex in domestic and wild animals in sleeping sickness foci in Cameroon. The presence of T. b. gambiense DNA in $6.74 \%$ sheep, $3.03 \%$ goats and $0.32 \%$ pigs in sleeping sickness foci does not only confirm the role of pigs as reservoirs of HAT reported in Cameroon (Nkinin et al., 2002; Penchenier et al., 2005; Simo et al., 2006), but also suggests the implication of other domestic animals like sheep and goats already reported in Congo by Scott et al. (1983) and Noireau et al. (1989).

The relative importance of the role of different animal species as reservoir hosts is complex. In this study, pigs are less infected by T. brucei s.l. than dogs, sheep and goats; yet, pigs are less infected by $T$. $b$. gambiense than goats and sheep. Further, analysis of blood meals shows that Glossina feed more on pigs than on the other domestic animals (Laveissière et al., 1985; Simo et al., 2008). These results can be explained not only by differences in the susceptibility of the animals, but also by their lifecycles. Whereas dogs, sheep and goats are maintained for many years in the foci and have prolonged contact with Glossina with possible infection, pigs hardly ever live for longer than one year. Young pigs 1 to 2 months old are usually reared from the beginning of the years and generally sold for various financial and ceremonial needs by September and December. In addition, pigs have a self-cure capacity and so can eliminate a T. b. gambiense infection (Penchenier et al., 2005).

Comparison of study sites shows that animals from Bipindi and Fontem had the highest proportion of positive results with QBC and CATT, suggesting a greater frequency of contact with Glossina and trypanosomes, as observed by Simo et al. (2006) for pigs, and by Morlais et al. (1998) for Glossina in Fontem. The high prevalence of T. brucei s.l. and T. b. gambiense in animals in the sleeping sickness foci of Campo and Bipindi corroborate the results of a medical surveillance team that identified many patients in these foci (rapport PNLTHA, 2007, 2009).

The low number of positive results obtained in Doumé may be a reflection of the low transmission rate of HAT, since only three patients have been identified since 2000 by the National Program against HAT (PNLTHA). Further, this should be considered together with the very low apparent density (number of flies/trap/day) of the unique vector Glossina fuscipes in Doumé (0.11) as compared to the relatively higher density for the Glossina palpalis palpalis vector in Bipindi (1.89), Campo (2.06) (Mbida Mbida, 2006) and Fontem (4.96; Njitchouang et al., personal communication). In addition, the frequency of transmission of trypanosomes in each locality is not stable; it can vary according to the frequency of diagnosis and treatment of patients which drastically reduces the human reservoir population; it can also vary according to the frequency of the cam- 
paign against Glossina, which also reduces the transmission of all Glossina-transmitted trypanosomes. Diagnosis and treatment, and vector control explained the huge decrease of $T$. $b$. gambiense group 1 prevalence in wild animals in Bipindi from $10 \%$ in 1999 to $0.1 \%$ in 2001 (Njiokou et al., 2006). The absence of T. b. gambiense infected pigs in Fontem-Centre in this study, compared to $15 \%$ reported in Fontem-North in 1999 (Nkinin et al., 2002) could also result from the reduction in transmission because of the annual medical surveillance organized in the focus by the PNLTHA since 2000.

This study has shown that, in addition to pigs already known to be reservoir hosts of $T$. $b$. gambiense group 1 in sleeping sickness foci in Cameroon, sheep and goats may also be infected in natural conditions. Although the importance of these animals as possible reservoir hosts for $T$. b. gambiense group 1 still need to be further explored, it is worthy of note that the prevalence of T. b. gambiense in the animals in the different study sites seems to reflect the general level of transmission of HAT. This probably indicates the implication of the animals infected with T. b. gambiense in the epidemiology of HAT in Cameroon.

\section{ACKNOWLEDGEMENTS}

T This work benefited from funding from "Jeune Equipe Associée" Trypanosomose of IRD and from Unite Mixte de Recherche 177 of IRD. The laboratory phase of this work was done in OCEAC and in the University of Yaounde I.

\section{REFERENCES}

Asongany T., Sede Mbakop J. \& NGu J.L. Trypanosomiasis in Mbam division, Cameroon. Parasitological and immunodiagnosis examination of the domestic animal population. Annales Universitaires des Sciences de la Santé, 1986, 3 (3), 181-189.

Asonganyi T., Such S. \& Tetuh M.D. Prevalence of domestic animal trypanosomiasis in the Fontem sleeping sickness focus, Cameroon. Revue d'Elevage et de Médecine Vétérinaire des pays Tropicaux, 1990, 43 (1), 69-74.

BAILEY J.W. \& SMITH D.H. The use of acridine orange $\mathrm{QBC}^{\circledR}$ technique in the diagnosis of African trypanosomiasis. Transaction of the Royal Society of Tropical Medecine and Hygiene, 1992, 86, 630.

Bouteille B., Oukem O., Bisser S. \& Dumas M. Treatment perspectives for human African trypanosomiasis. Blackwell Publishing Fundamental and Clinical Pharmacology, 2003, 17, 171-181.

Gibson W.C. Will the real Trypanosoma brucei gambiense please stand up. Parasitology Today, 1986, 2 (9), 255-257.

Gibson W.C., Mehlitz D., Lanham S. \& Godfrey D.G. The identification of Trypanosoma brucei gambiense in Libe- rian pigs and dogs by isoenzymes and by resistance to human plasma. Tropenmedizin und Parasitologie, 1978, 29, 335-345.

Grébaut P., Bodo J.M., Assona A., Foumane Ngame V., Njiokou F., Olivier G., Soula G. \& Laveissière C. Recherche des facteurs de risque de la Trypanosomiase Humaine Africaine dans le foyer de Bipindi au Cameroun. Médecine Tropicale, 2001, 61, 377-383.

Guedegbe B., Verhulst A., Van Meivenne N., Pandey V.S. \& Doko A. Indications sérologiques de l'existence d'un réservoir animal sauvage de Trypanosoma brucei gambiense dans la réserve de la biosphère de Pendjari en République du Bénin. Annales de la Société Belge de Médecine Tropicale, 1992, 72, 113-120.

Herder S., Simo G., Nkinin S.W. \& Njiokou F. Identification of Trypanosomes in wild animals from southern Cameroon using the polymerase chain reaction (PCR). Parasite, 2002, 9, 345-349.

Hoare C.A. The trypanosomes of Mammals, in: A Zoological Monograph. Blackwell Scientific Publications, Oxford and Edinburgh, 1972.

Jamonneau V., Ravel. S., Koffi M., Kaba D., Zeze D.G., Ndri L., Sane B. Coulibaly B., Guny G. \& Solano P. Mixed infections of trypanosomes in tsetse and pigs and their epidemiological significance in a sleeping sickness focus of Côte d'Ivoire. Parasitology, 2004, 129, 693-702.

Komoin-Oka C., Truc P., Bengaly Z., Formenty P., Duvalet G., Laguinie F., RaAth J.P., N'Depo A.E. \& Leforban Y. Étude de la prévalence des infections à trypanosomes chez différentes espèces d'animaux sauvages du parc national de la Comoé en Côte d'Ivoire : résultats préliminaires sur la comparaison des trois méthodes de diagnostic. Revue d'Élevage et de Médecine Vétérinaire des Pays Tropicaux, 1994, 47, 189-194.

LAPEYSONNIE L. Géométrie et passion : la lutte contre la maladie du sommeil. Annales de la Société Belge de Médecine Tropicale, 1992, 72 (1), 7-12.

Laveissière C., Couret D., StaAk C. \& Hervouet J.P. Glossina palpalis palpalis et ses hôtes en secteur forestier de Côte d'Ivoire. Relation avec l'épidémiologie de la Trypanosomose Humaine. Cahier ORSTOM, Série Entomologie médicale et Parasitologie, 1985, 23, 297-303.

Magnus E., Veroost T., Van Meirvenne N., Le Ray D. \& WérRY M. A Card Agglutination Test with stained trypanosomes (CATT) for the serological diagnosis of Trypanosoma brucei gambiense trypanosomiasis. Annales de la Société Belge de Médecine Tropicale, 1978, 58, 169-176.

MBida MBida J.A. Glossines et transmission de la trypanosomiase humaine africaine en zone forestière du sud Cameroun. Thèse de Doctorat de $3^{\text {ème }}$ Cycle, Université de Yaoundé 1, 2006, $154 \mathrm{p}$.

Mehlitz D., Zilmann U., Scott C. M. \& Godfrey D.G. Epidemiological studies of the animal reservoir of gambiense sleeping sickness. III. Characterization of Trypanozoon stocks by isoenzymes and sensitivity to human serum. Tropenmedizin und Parasitologie, 1982, 33, 113-118.

Mehlitz D. Le réservoir animal de la maladie du sommeil à Trypanosoma brucei gambiense. Études et Synthèses de l'IEMVT, 1986, 18, $156 \mathrm{p}$. 
Mehlitz D., Zillmann U. \& Sachs R. The domestic pigs as carriers of Trypanosoma brucei gambiense in West Africa. Tropenmedizin und Parasitologie, 1985, 36 (3), 18.

Morlais I., Grébaut P., Bodo J.M., Djoha S. \& Cuny G. Characterization of trypanosome infections by polymerase chain reaction (PCR) amplification in tsetse flies in Cameroon. Parasitology, 1998, 116, 547-554.

Moser D.R., Cook G.A., Ochs D.E., Bailey C.P., McKane M.R. \& Denelson J.E. Detection of Trypanosoma congolense and Trypanosoma brucei subspecies by DNA amplification using polymerase chain reaction. Parasite, 1989, 99, 5766.

Njiokou F., Laveissière C., Simo G., Nkinin, S., Grébaut P., Cuny G. \& Herder S. Wild fauna as a probable animal reservoir for Trypanosoma brucei gambiense in Cameroon. Infection, Genetics and Evolution, 2006, 6, 147-153

Nkinin S.W., Njiokou F., Penchenier L., Grébaut P., Simo G. \& HeRder S. Characterization of Trypanosoma brucei s.l. subspecies by izoenzymes in domestic pigs from the Fontem sleeping sickness focus of Cameroon. Acta Tropica, 2002, 81, 225-232

Noireau F., Gouteux J.P., Toudic A., SAmba F. \& Frézil J.L. Importance épidémiologique du réservoir animal à Trypanosoma brucei gambiense au Congo. 1. Prévalence des trypanosomoses animales dans les foyers de la maladie du sommeil. Tropical Medecine and Parasitolology, 1986, 37, 393-398

Noireau F., Paindavoine P., Lemesre J.L, Toudic A., Pays E., Gouteux J.P, Steinert M. \& Frezil J.L. The epidemiological importance of animal reservoir of Trypanosoma brucei gambiense in the Congo. 2. Characterization of Trypanosoma brucei complex. Tropical Medecine and Parasitology, 1989, 40, 9-11.

Penchenier L., Simo G., Grébaut P., Nkinin W.S., Laveissière C. \& Herder S. Diagnosis of human trypanosomiasis Trypanosoma brucei gambiense in Central Africa by polymerase chain reaction. Transaction of the Royal Society of Tropical Medicine and Hygyene, 2000, 94, 392-394.

Penchenier L., Alhadji D., Bahebegue S., Simo G., LaveisSIÈre C. \& Cuny G. Spontaneous cure of domestic pigs experimentally infected by Trypanosoma brucei gambiense. Implications for the control of sleeping sickness. Veterinary Parasitology, 2005, 133, 7-11.

Scott C.M., Frézil J.L., Toudic A. \& Godfrey D.G. The sheep as a potential reservoir of human African trypanosomiasis in the Republic of Congo. Transaction of the Royal Socety of Tropical Medecine and Hygiene, 1983, 94, 397-401.

Simo G., Asonganyi T., Nkinin S. W., Njiokou F. \& Herder S. High prevalence of Trypanosoma brucei gamabiense group 1 in pigs from the Fontem sleeping sickness focus in Cameroon. Veterinary Parasitology, 2006, 139, 57-66.

Simo G., Njiokou F., Mbida Mbida J.A., Nuitchouang G.R., Herder S., Asonganyi T. \& Cuny G. Tsetse fly host preference from sleeping sickness foci in Cameroon: epidemiological implications. Infection, Genetics and Evolution, 2008, 8, 34-39.

Reçu le 22 avril 2009

Accepté le 3 novembre 2009 